\title{
Wisdom and Mystical Thoughts on The Mirror-Tiles Art in Safavid Architectural Space and its Relationship With Sufism
}

\author{
Naeim Sepehri \\ Memar Srl Unipersonale \\ Via Jacopo da Corte, 45, 35028 Piove di Sacco PD, Italy \\ E-mail: naeim.sepehri@yahoo.com
}

Abstract: The Mirror-tiles artwork is one of the latest initiatives of Iranian spiritual art which with its symbolic expression and mysterious character, conveys the revelations and mystical thoughts in the cover of matter and form to its audience and affects them consciously and unconsciously. This art is an esoteric language to convey intuitive concepts and to remind the way of their inherited life from the predecessors as traditional art has always been based on symbols and allegories and expresses the spirit of its time. The first peak of the Mirror-tiles used in architectural spaces in Iran coincided with the fusion of Sufism and Shi'ism in the early period of the Safavid Empire. The Safavid dynasty had Sufi roots and lineage, and among the Sufis, the inner language is the language of Shari'a and Truth, and the tools of that language are the symbol and indication. Has been rejected or neglected due to a lack of interest and attention to the registration of special documents, the secrets governing this system, new historical conditions, and profound and obvious developments in the realm of contemporary history. With the aim of the influence of the Persian mystical thoughts about the Mirror, this study with the available historical and contemporary sources and analyzing them deals with the hidden meanings in this art and reveals its connection with Sufism and Mysticism through mystical literature and its historical process.

Keywords: Mirror-tiles art, Iranian-Islamic Architecture, Safavid dynasty, Mystical thoughts, Sufism 


\section{A. InTRODUCTION}

"How many points and issues have been omitted, left unsaid and unwritten in the context of debates that have previously been of a Primary nature, and have been left out; One of the important issues in the aesthetic of the history of art in the Islamic era, especially the Architecture and Persian poetry, which is still untouched remained, and the field of research is open, is the research on the allegorical expression of the Mirrors and is the Islamic mystical thoughts of Iranians." (MullaSalehi, 1998) There's not much information about the Mirror-tiles art creators of the Safavid period (1736$1501 \mathrm{CE}$ ) because the culture that governs Persian art and architecture, is the culture of 'Master-Apprentice' education and there are certain secrets to these specific orders that govern the system. but in the generalities left from the point of view of the elders and masters of the Islamic period and historical evidence, can find commonalities in the expression of allegories that somehow represent the homogeneity of the creators of Islamic arts and mystical thought in the Persian traditions. "The lack of theoretical studies on Iranian Mirror-tile artworks has made it difficult to conduct scientific and systematic research on it. In general, what has been written so far generally introduces the history of the Mirror-tile." (Poorzarrin, 2014) Among the researchers, pointed to Mohammad Hassan Samsar and Yahya Zaka in the Great Islamic Encyclopedia (1381), Arthur Upham Pope in his book A Survey Of Persian Art (1969), Lotfollah Honarfar in the Historical treasures of Isfahan, book (1972), Mohammad Yousef Kiani in his book: Decorations Related to the Architecture of the Islamic Era (1998), Hassan Bolkhari Ghahi's researches in the Mystical Foundations and Islamic Architecture, book (2006) and most recently the Collection of Art-works of 'Monir Shahroudy FarmanFarmaian' who has paid attention to Mirror-tiled artworks in the most visual languages. [monirff.com]

In an article entitled: Recognition of Mirror-tile Patterns in Qajar Monuments at Shiraz, by Mohammad Aliabadi and Somaye Jamalian, the results indicate that Mirror-tile art was used to decorate royal buildings and shrines and concludes "the Mirror-tile can be interpreted as a religious and traditional art” (Aliabadi, \& Jamalian, 2012) Another article entitled: The importance of Mirror-tiles artwork in the Safavid and Qajar periods, by Qassem Gholamrezania Fallah, Ruhollah Aziznejad, and Ali Vaezi, which reviewed the history of this art and divided it into three categories: residential, pilgrimage, and 
Naeim Sepehri: Wisdom and Mystical Thoughts on The Mirror-Tiles Art in Safavid Architectural Space and its Relationship With Sufism (page 291-314)

garden. They have studied that the types of Mirror-tile artworks are different in these three types of uses and have studied the crystallization of this exquisite art in especially mosques and holy places and concludes: "In modern times, Mirror-tile art has gone beyond royal palaces and places of worship 'holy places' [Picture 1], and traditional methods in combination with innovations have been widely used in public places and even homes." (Fallah G, Aziznejad, \& Vaezi, 2016) And in the article entitled: Study of the wisdom of the Mirrortile in Islamic-architecture, by Nahideh Taghavi, she considered Mirror-tile art-work as religious and traditional art. (Torkaman, \& Farshchian, 2017) "Mirror in Persian literature has meant Purity, Clearness, Truth, and Enlightenment, has been used by artists in Islamic architecture. Mirror-tiles art is completely Islamic and contains Islamic geometric shapes. Light is the absolute light of God and also Light in Islam is a symbol of guiding believers from darkness and straying, so the reflection of light from mirrors with many fractures and various designs, in addition to creating a beautiful atmosphere, can also give a sense of Unity and remind Oneness of God. In places where Mirror-tile has been made, the geometric shapes of the mirror and the presence of light and its interaction on the mirror have created a special mystical atmosphere that is influenced by the verses of the Quran." (Taghavi, 2015).

This research's data was collected and analyzed by comparative studying library resources such as books, articles, pictures, historical texts, and authentic websites, [Many of them were in the original Persian language, that translated by the Author]. With the background of years visit of most of the remaining historical buildings, and communication and the personal interviews with related Masters and Profs in Iran [That themselves were less interested in exposing these issues] along with scientific and practical training in Mirror-tile. Towards the attainment of the purpose of the research and to create a basis for further research in these cases.

The present research shows some limitations that can be summarized as follows: the first limitation is that it was very complicated and difficult to understand, interpret, and translate the old Persian mystical expressions [notused today] because words in Persian mystical literature are like bricks in an architecture that the way they are placed together creates a building. The second limitation is the special mystery (secrets) that governs the Mystical Orders. [what carries mystery or what emerges through mystery, must be living in it and experience it, before it was known. (MullaSalehi, 1998)] And 
finally, the primary use of mirrors was in buildings from the early Safavid era buildings that were removed or destroyed and no longer exist today.

\section{B. Theoretical Framework}

\section{History of Mirror and Mirror-tile Artwork}

Thousands of years before the human knew about metals and made metalmirrors, human used water as a mirror. The ancient Greek myth of Narcissus confirms this. The mirror is probably one of the first human-made tools, made with the knowledge of metal and the ability to polish it. (Riazi, 1996: 8) The manufacture and use of glass-mirrors became common in Europe from the beginning of the $13^{\text {th }}$ century $\mathrm{CE}$ and in the middle of the $17^{\text {th }}$ century $\mathrm{CE}$ spread throughout Europe and its use increased; Such mirrors were very rare and expensive. (Riazi, 1996: 10) The use of pieces of glass-mirrors and mirror artwork as it is now observed, has economic origins and roots. Glass mirrors, which had been brought to Iran from the $16^{\text {th }}$ century as one of the items imported from Europe, especially from Venice, break during transportation. Iranian artists found an innovative way to take advantage of these broken pieces and used them as Mirror-tiles. (Riazi, 1996: 12) "Using broken mirrors as recycling creative art by Muslim artists," (MullaSalehi, 1998) because Being wasteful is an act that is abhorred in Islam. [refer to Quran, 17:27] The following Persian poem from the 'Kashmiri' [Persian poet of India in the $17^{\text {th }}$ century] indicates this fact:

"Every part of my broken heart is the grass from His look

The mirror after the broke is the collection of mirrors [Mirror-tile]"

— Binesh Kashmiri (Azaimabadi, 2012: 244). [Translation: Author]

The material used by the Muslim craftsman was ordinary and humble, and his tools were very simple; His work, however, was unique in that it shared human dignity as a 'representation of God on earth.' (Burkhart, 2007: 79) In the $19^{\text {th }}$ century, when Mirror-tile became more popular, more delicate, and more accurate, thin mirrors were made in Germany and sent to Iran. These mirrors could easily be used by Iranian Mirror-tile makers [Picture 5] in any geometric shape. At the end of the $19^{\text {th }}$ cent ury, small pieces of mirrors became triangles, rhombuses, and hexagons, and artists used them. The most common design in mirror work is the design known as 'Girih', which is unparalleled in terms of the variety of shapes, and various applications of different fields 
Naeim Sepehri: Wisdom and Mystical Thoughts on The Mirror-Tiles Art in Safavid Architectural Space and its Relationship With Sufism (page 291-314)

of Iranian-Islamic art. (Riazi, 1996: 12) Girih [Picture 4] is an integrated combination of various geometric patterns that are coordinated and complemented in a specific framework to form a geometric pattern. (Ardalan, \& Bakhtiar, 2015: 70) Countless drawings, beginningless and endless periods, symbolize Multiplicity in Unity and express endless Creation. (Madkour, 2008) Mirror-tile artwork should be considered as the last initiative of Iranian artists in the group of fine arts that Iranians have used in interior architecture and interior design. Performers of this branch of art, which requires a lot of precision, elegance, and patience in their work, have always been and are Iranian artists since the inception. By creating regular and more geometric shapes and decorative designs from small and large pieces of mirrors on the interior surfaces of the building, the Mirror-tile artist creates a bright and glittering atmosphere, which results in the continuous reflection of light in countless pieces of mirrors and creates a bright, pleasant and dreamy space. (Kiani, 1997: 239) The architect with the use of mirrors in small dimensions and different geometric shapes, by putting together these small pieces has created a great order. Helen Gardner has said about the art of Mirror-tile work in the famous book, Art through the ages: "The peak of the art of Mirror-tiles in old Persia can be traced to the Safavid and Qajar era."

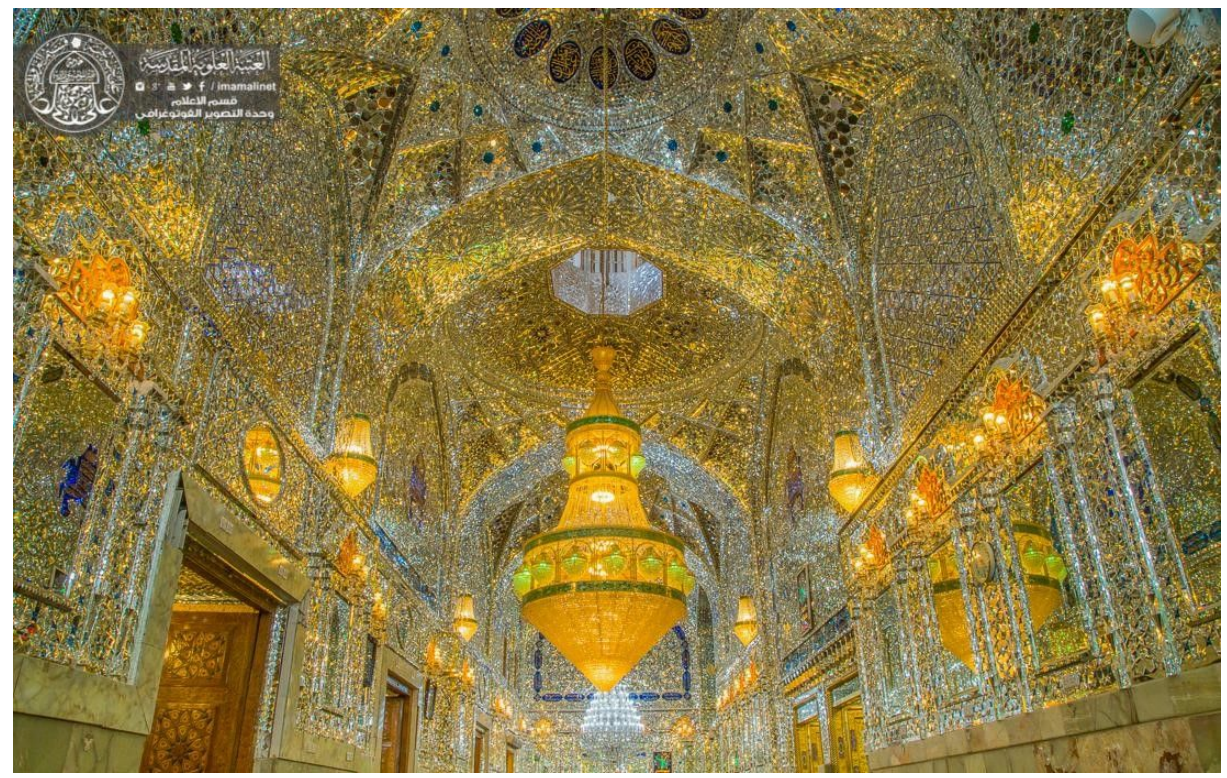

Picture 1. Mirror-tile decoration in Holy Shrine of Imam Ali, Najaf, Iraq (The Official Website of Imam Ali Holy Shrine - 2016) 


\section{Safavid Empire (1501 - 1722 CE)}

According to the available documents, it seems that a mirror was used for the first time in decorating the building of 'Tahmasp I' Govern-House [the son and successor of 'Ismail I' the founder of the Safavid dynasty] in 'Qazvin'. Knowing that the construction of the Qazvin 'Divankhaneh' [Courthouse] began in $1544 \mathrm{CE}$ and ended in $1558 \mathrm{CE}$, it can be concluded that the history of the use of mirrors in the building dates back to at least the middle of the $16^{\text {th }}$ century CE. The use of mirrors in buildings, which began in Qazvin, after the transfer of the capital from Qazvin to 'Isfahan', spread in this city and the other Iranian cities such as Ashraf (Behshahr), and this art was used in decorating many palaces of the Safavid era. (Riazi, 1996: 11).

The Safavid era is considered one of the most important historical periods in Iran, because nine hundred years after the destruction of the Sassanid Empire; A centralized Persian monarchy was able to rule over all of Iran at that time. After Islam, several Persian monarchies came to power, but none of them were able to cover all of Iran and create unity among the Iranian people. Also, this period is one of the three stages of the golden age of Islam and the peak time of Islamic civilization (Najafi, 2009: 249).

The dynasty founded by Ismail I would rule for over two centuries, being one of the Greatest Iranian Empires and at its height being amongst the most powerful empires of its time, ruling all of present-day Iran, Azerbaijan Republic, Armenia, most of Georgia, the North Caucasus, Iraq, Kuwait, and Afghanistan, as well as parts of modern-day Syria, Turkey, Pakistan, Uzbekistan, and Turkmenistan. [Picture 2] It also reasserted the Persian identity in large parts of Greater Iran. The legacy of the Safavid Empire was also the revival of Iran as an economic stronghold between East and West, the establishment of an efficient state and bureaucracy, its architectural innovations, and its patronage for fine arts (Grantovski, 2006). 
Naeim Sepehri: Wisdom and Mystical Thoughts on The Mirror-Tiles Art in Safavid Architectural Space and its Relationship With Sufism (page 291-314)

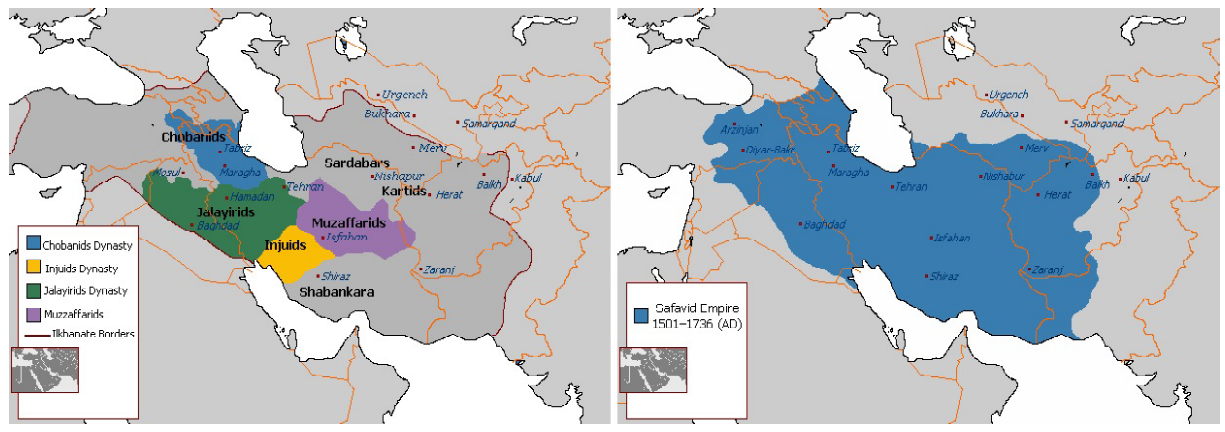

Picture 2. Map of Iran before and after the Safavid Empire (tamadonema.ir)

'Ismail I' Emperor of Persia, son of 'Sheikh Haydar', was the sheikh of the 'Safavid Tariqa' [Sufi way] and a direct descendant of its founder, sheikh 'Safi-ad-din Ardabili'. Ismail was the last in this line of hereditary Grand Masters of the Sufi order, before his ascent to a ruling dynasty. According to 'Ahmad Kasravi', "the father of Ismail I was the main founder of the Safavid dynasty and the 'Sufi Movement' to form the government." And Ismail I's Grandfather was called by the disciples 'Perfect-Guide' and the owner of the guardianship prayer rug. (Jamei, 2000: 129).

When Akbar, the third Emperor of the Mughal dynasty, had no living heir at age 28, he consulted with a Sufi [an Islamic mystic], 'Shaikh Salim', who assured him a son would come. Soon after, when a male child was born, he was named 'Salim'. Upon his ascent to the throne in 1605, Prince Salim decided to give himself the honorific title of 'Nur ud-Din' [Light of Faith] and the name 'Jahangir' [Seizure of the World]. (Roshna K., 2018) The last wife of Emperor Jahangir, 'Nur Jahan' [Light of the World] in original Persian name 'Mehr-un-Nissa' [Women's Sun] was born 1577 CE in 'Kandahar' of Safavid empire [present-day Afghanistan], into a family of Persian [present-day Iran] nobility. Her paternal grandfather, 'Khvajeh Muhammad-Sharif', was first a minister of the governor of 'Khorasan', and later was in the service of 'Tahmasp I', who made him the minister of Isfahan. (Banks F., 1993: 8) According to the Dutch traveler Francisco Pelsaert, her patronage of architecture was extensive, as he notes, "She erects very expensive buildings in all directions 'sarais' [taken from the Persian 'Saray'], or halting places for travelers and merchants, and pleasure gardens and palaces such that no one has seen before." (Pelsaert, 1972: 50). 
"If in appearance the kings have an uprising ahead But inwardly they constantly look at the Sufis"

— Persian poem in the (Picture 3), [Translation: Author]

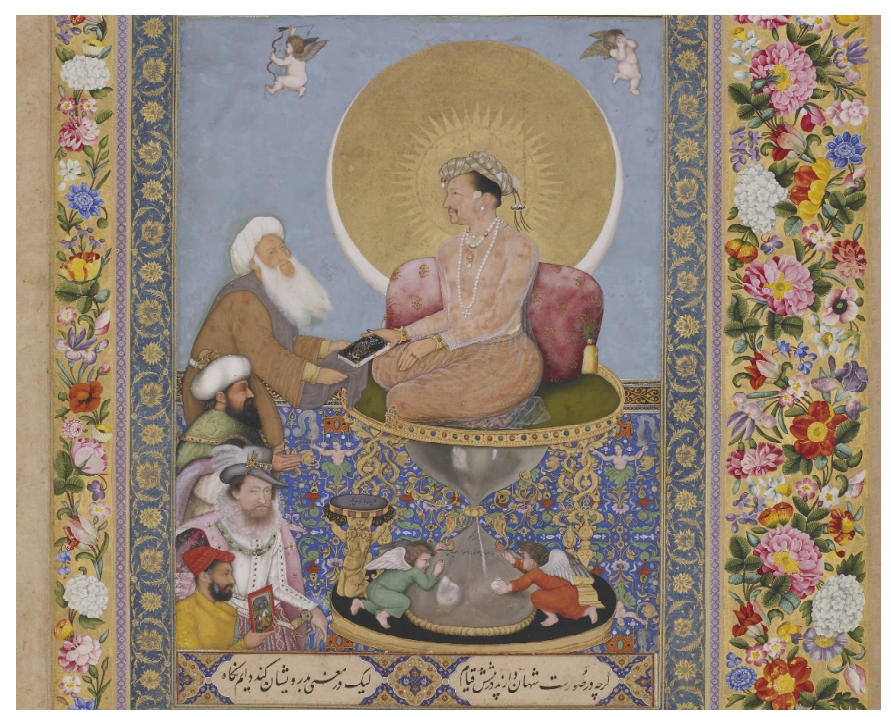

Picture 3. Jahangir (1605-1627 CE) Preferring a Sufi Shaikh to Kings (khanacademy.org - Roshna Kapadia)

\section{Sufism and Mysticism}

In an article entitled: Research on the position of Shi'ism and Sufism in the political structure of the Safavid state, by Yousef Motavi Haghighi, the Safavid dynasty as the first dynasty of the Iranian [Persian] government who were able to create a bold and fruitful combination between Sufism and Shi'ism [Islamic Mysticism] and considered the Sufism as the second source of power for the Safavid Empire after Shi'ism. "They showed that they traveled in the world of Sufism and the Safavid Sufis, who obeyed their leaders to the death, was the most important military tools of the Safavid in gaining political power." (Motavali.H., 2008). "The word Shi'i also referred to as Shi'ite, means one who is a partisan, or supporter, in Arabic. It is about Imam 'Ali [Picture 1. Shrine], prophet Muhammad's cousin and son-in-law, who many considered his rightful successor." (Payind, A., \& McClimans, M., n.d.)

Islamic mysticism has a wide field and is intertwined with the Sufi way, and in some cases, there is an equal or mixed interpretation of both. These two are sometimes used interchangeably. Since the truth of Islamic mysticism, 
Naeim Sepehri: Wisdom and Mystical Thoughts on The Mirror-Tiles Art in Safavid Architectural Space and its Relationship With Sufism (page 291-314)

including Sufism, general and scientific-terminological content can be referred to as Islamic mysticism, and the popular method in Islam is often referred to as Sufism. Some writers such as 'Morteza Motahhari' have also presented two types of perceptions of these two concepts and consider mysticism as a scientific aspect, and Sufism as its social dimension. (Motavali.H., 2008).

Among the Sufis, the inner language is the language of Shari'a [the Way], and Truth, which is used to express the meanings and subtleties of the supernatural, and the tool of that language is symbols and indication so that, their thoughts are not made available to the illegitimate and the incompetent people. Also, the general language is insufficient in expressing the Meanings, Ecstasies, and Enthusiasm of their Experience. (Jilani, 2013, 26) The Message that has always been, and is, and will be, like a pearl inside the oyster is in some way both achievable and not, in the interpretation of 'Abd al-Razzaq Kashani', "It is far from reason and narration and they will not be discovered except by the discovery Masters." These mysteries are not stat us and contractual symbols but are based on the system of existence. (Awani, 1996) Decipherment is also realized in the light of inner experience because, in mystical experiences, the mystic discovers the hidden meanings of existence. (Karimian.S, 2013: 88) The symbol is not the vague thing or the result of a sensorial tendency, but the symbol is the language and expression of the soul. (Burkhart, 2007: 111) According to Ibn Arabi, the cryptographic [and symbolic] expression is to hide the truth of all the elements and keep it away from the incompetents, as well as the danger of openly plotting a point of view. (Madkour, 2009).

"Beyond Islam and unbelief, there is a wide desert plain

For us, there is a 'passion' amid that expanse [place]

The mystic who reaches there will prostrate [will put the head in]

There is neither Islam nor unbelief nor any 'where' [in] that place"

— Rumi Balkhi (ganjoor.net). [Translation: Author]

The rise of 'Sheikh Safi al-Din Ardabili' Grand-Master of Sufism, and ancestor of 'Ismail I', is considered a turning point in the formation of the Safavid Empire. In his youth, he sought guidance among the ascetics, finally in one of the Caspian coastal villages, he visited his lost target 'Sheikh Zahid Gilani', one of the Great Sufi Masters of Iran, and stayed with him for 25 years, then he returned to his hometown. (Motavali, 2008) Ismail I, one of his 
descendants and the last in this line of hereditary Grand Masters of the Sufi order, in his childhood, many years after his ancestor, after escaping from the government troops who wanted to arrest him, had run away to the same area and during his secret stay in the 'Gilan' province, he was trained by the Great Master of Sufism and Mysticism 'Sheikh Mohammad Lahiji', who after Ismail ascended the throne became the highest religious and spiritual authority and prime minister in the Safavid Empire. (Khavandmir, 1991) Also from 'Mohammad Lahiji', survived an old manuscript book called The Key of Miracles in the Explanation of 'Golshane-Raz' which interprets Mahmoud Shabestari's mystical thoughts in the allegory of the appearance of the Sun of Truth in the Mirror of the universe.

"The world of the Meaning has no end

Where does can be enough the word

Any meaning that comes from enthusiasm

Where can to find an interpretation for that"

- Shaikh Mahmoud Shabestari, 'the Persian mystic and poet' (ganjoor.net). [Translation: Author]

\section{Spiritual and Traditional Art}

Islamic art is thought-provoking from an artistic point of view. In other words, it especially gives the spiritual situation that tends towards the interior and confrontation with the Divine presence. It can be unequivocally acknowledged that Islamic art, in its salient instances, deals directly with the sacred and absent art of the individual; The artist disappears in his work or in a tradition that guarantees the truth of the work. (Burckhardt, 2007: 143) Decorating or transforming a surface into a texture of colors or fluctuations in light and shadows prevents the viewer's mind from focusing on the particular form that says 'I'. (Awani, 1996: 103) Today, nothing is more valuable than the eternal truth of the message given by tradition. A message that is relevant today because it has always been relevant. A message belonging to time while it has been, and is, and will be, from eternity to eternity. The problem of tradition is the problem of established principles, its heavenly origin, and application of these principles in different moments of time and place (Ardalan, \& Bakhtiar, 2015: 15) 'Ibn Arabi' for the first time organized the theory of the Unity of Existence coherently and systematically. (Madkour, 2008) In his works, he has not devoted an independent chapter to the 
Naeim Sepehri: Wisdom and Mystical Thoughts on The Mirror-Tiles Art in Safavid Architectural Space and its Relationship With Sufism (page 291-314)

discussion of art; the keyword for studying his views on art is the word Creation. He considers the world as the creation of God and the Divine art and says that "It is through art [Creation] that God has appeared in the world." (Hekmat, 2006: 73) Also, he believes that 'Truth' has appeared in the realm of existence with art. It must therefore be said that the appearance of Truth is artistic in the realm of absolute imagination; this art is a place of inner meeting and appearance of truth. It is from here that when we come to human art, we see that human artistic creativity is like divine artistic creativity. We can inquire about the similarity between the art of God and the art of humans in different ways. Divine art is preceded by a desire to appear; The same is true of human art; That is, human, like God, wants to be known, and it is this desire to be known that steer him to create an artwork. (Hekmat, 2006: 97) Human art, in any case, indicates that the artist has reached a point where he has to give birth to art so that he cannot carry alone what he has achieved and wants to share it with others. (Hekmat, 2006: 99) So what is artistically done is to meet and observe existence with the existing. (MullaSalehi, 1998).

In the philosophical description of the journey of the soul in Hegel's book, The Phenomenology of Spirit, we reach from the lowest position, from sensory perception to the highest position, the absolute soul. Also, considering art as a product of the artist's mind does not mean accepting that the artist has created completely consciously, so it cannot be said that art expresses the conscious feelings and emotions of the artist, but it can be said that the artist himself is not aware of the secret of these feelings. It is the spirit of the time or the spirit of the era. He concludes that in art, creation is important, not the expression of something that already existed. Therefore, ambiguity and Confidentiality for spiritual art is a fundamental point. "Sacred art is not necessarily made of images, it may be nothing more than the tacit objectification of an inner state of thought and meditation, in which case reflection is not mental imagery, but qualitatively transforms the environment into a balance in the center of gravity. It is the invisible world of the unseen." (Awani, 1996: 79) At the heart of any form of traditional art is the spiritual nature of sacred art, as well as the specific material body that has historically existed before. 'Image' in Islamic art is rooted in Quranic revelation, and besides, art has a relation to the esoteric aspect or Truth of the Quran, so one must first reach this position to reach the origin of this art; He reminds us that art is also related to material things, that is, to the lowest level of reality, and that by this 
'Hermes' principle that "what is at the lowest level is a symbolic form of what is at the highest level" art is a reflection of the highest level. The esoteric and inherent truth of revelation is made possible by art. Islamic art appears from a single thing and returns to it, and tells of the appearance of unity in plurality, and plurality in unity, which is the alphabet of all truths. Anyone who is not intimate with Ibn Arabi's mystical teachings [Unity of Essence] and 'Abdul Karim Jili', Ahmad al-Alawi, 'Isa Nur ad-Din' [Frithjof Schuon], is unable to understand this. (Burckhardt, 2007: 19) Muslim philosophers have considered Hermes or 'Idris' [the Prophet] to be the source of Wisdom or Sophia and among the first Philosophers and Grand Teachers. According to 'Suhrawardi', Hermes was the source of wisdom or Sophia, and 'Mulla Sadra' named him as the father of philosophers [Abu al-Hakma] and the Master of Masters [in the School of 'Illumination']. (Mohajeryzadeh, 2015)

\section{Wisdom of Mirror}

"There is no Mirror in the world except the Face of Friend

The Face of that Friend which is from another Land"

— Rumi Balkhi (ganjoor.net). [Translation: Author]

From The Brethren of Purity or The Brethren of Sincerity [Ikhwan AlSafa] point of view, the mystics are the creators of art and mystery; Art is born of wisdom, in other words, art is nothing without wisdom. (Bolkhari, 2018: 135) In a world where all its phenomena have symbolic significance that is manifested by interpretation, the human is forced to interpret and achieve the hidden inner truth of things. Wisdom is a tool that can perform interpretation and in traditional expression is understood as enlightenment with revelation. (Ardalan, \& Bakhtiar, 2015: 35) Kinship, the allegorical relation and symmetry of the Mirror and Existence, the Mirror and the Soul, and the Mirror and the Spiritual world go back to ancient and even older times. In the later and newer era of the Bronze-Age, there is more important evidence that is full of deep and cryptic meanings and the allegorical relationship of Water and Mirror or any object whose smooth and transparent surfaces can place and reflect the Image, Role, and Face. In the spiritual world, goodness, beauty, inner purity is appearance and observable. (MullaSalehi, 1998) In Persian poetry and mystical literature, the richness and variety of mirror allegory and the symmetry of the mirror with existence are much broader and richer than the mirror decoration of spaces in Islamic architecture of Iran. Sometimes there 
Naeim Sepehri: Wisdom and Mystical Thoughts on The Mirror-Tiles Art in Safavid Architectural Space and its Relationship With Sufism (page 291-314)

are cases as if Persian poetry, like Iranian architecture, has adorned its space with mirrors with words.

"The photo of your Face that fell into the glass mirror

Mystic fell into a crude fantasy out of laughter

The beauty of your face that appeared in the mirror

All these roles fell into the mirror of illusions

All these pictures of the wines and colorful patterns,

The sparkle of the Bartender's face was fell in the glass"

— Hafiz Shirazi, 'Persian mystic and poet' (ganjoor.net). [Translation: Author]

Thousands of years before the cognition of metal and the making of metal mirrors, humans used water as a mirror. The ancient Greek myth of Narcissus confirms this. (Riazi, 1996: 8) Water is the essence of all-nat ural elements and is permeable even in the narrowest corners of the world. The secret of life is found in water, every existence in its composition has an element of water because water is the main element. Everything has life because of water. The factor of water, which exists in different degrees in all things, corresponds to the identity of 'Truth' that is present in everything through movement." (Izutsu, 2000: 164). "And We created from water every living thing." (Quran, 21:30) "And on the earth, there are udifferentú neighboring tracts, gardens of grapevines, uvariousú crops, palm trees - some stemming from the same root, others standing alone. They are all irrigated with the same water, yet We make some taste better than others. Surely in this are signs for those who understand." (Quran, 13:4) "And Allah has created from water every living creature." (Quran, 24:45) "He is the One Who created the heavens and the earth in six Days and His Throne was upon the waters." (Quran, 11:7) Water and the Mirror have always been considered by Iranians as two symbols of Purity and Light, and the use of mirrors as one of the architectural elements may not be unrelated to this. (Riazi, 1996: 12) 'Sheikh Mahmoud Shabestari' has approximated the appearance of God $[\mathrm{Hu}]$ in the world, by comparing looking to the mind in the mirror. (Hekmat, 2006: 151)

"If you want to see the Source of Light

You will need another substance (stuff)

Because the eye has not tolerance,

The sun can be seen in the water

Makes it less bright than itself 
It increases your perception of it

Nothingness; is like the Mirror of absolute existence,

That reveals the picture of radiation the Truth

When the nothingness was in front of the everything

There was a Picture of Him produced in the result

Nothingness, like the Mirror of the universe, and human,

Like the eyes of a picture that person has hidden in Him

You are eye in the picture, He is the light

Who (never) seen his eye with the eye

Know the whole universe looks like a Mirror

That shines the Sun in every particle of it

Hidden under the screen of every particle

The life-giving Beauty of the Soul of $\mathrm{He}(\mathrm{Hu})$

[Hu] If appear on the high mountain of existence

Existence transforms to the paved from humiliation"

- Shaikh Mahmoud Shabestari, (ganjoor.net). [Translation: Author]

'Shabestari' has been able to connect the teachings of Ibn Arabi's mystical experience to Iranian romantic mysticism through the intermediate link of artistic imagination. [He is also influenced by Attar and Rumi] (Hekmat, 2006: 33) Imam Al-Ghazali [Persian Polymath] considers this meaning of the light to common people and a relative thing and says "Light is neither obvious nor revealer, in the case of blind people, so in addition to light, the nature of the seer is also a pillar of perception, and if we look carefully, Light is not the cause of perception, but the place of perception, so the power of sight in the name of the light, is the worthier than the visible object." (Al-Ghazali, 1985: 41)

"Open the eye of the heart to see the Essence

So see whatever is not visible"

- Hatef Esfahani, (ganjoor.net). [Translation: Author]

Unity of Essence, Plurality in Unity

"There is a Unit and there is nothing but Him

In Unity, there is no One but $\mathrm{Hu}$ "

- Hatef Esfahani, (ganjoor.net). [Translation: Author]

The concept of geometric patterns is based on the 'One' [Unit], and its 
Naeim Sepehri: Wisdom and Mystical Thoughts on The Mirror-Tiles Art in Safavid Architectural Space and its Relationship With Sufism (page 291-314) appearance in a world full of shapes and patterns. The traditional human understands these forms, as the character of numbers, as various aspects of the Creator. This concept is numerically based on symmetry and conformity in the dimensions, shape, and relative position of the components of a Whole. In this way, the concept connected to universal processes characterized by infinite expansion, into infinite directions, and infinite divisibility. Geometric patterns [Girih] as spatial concepts require space-filling patterns; Patterns or motifs that grow side by side. These patterns provide a set of infinite number pack forms. (Ardalan, \& Bakhtiar, 2015: 70) The intricate geometric patterns of a large number of geometric stars whose radii are merged into subtle, infinite interconnected patterns are a mystery symbol of human intuition in the degree to which one sees unity in plurality and plurality in unity. (Awani, 1996: 103) For the traditional architect, geometric patterns are like forms of plurality in unity. Repetitive patterns symbolize the thought of infinity and timelessness. The beauty and harmony seen in geometric patterns reflect a higher and deeper geometric order, the cosmic laws. The spiritual human seeks to discover geometric patterns as a means of understanding and reaching to the Creator. (Hejazi, 2009) The creation of the world starts from a single entity and descends in multiple states of existence. (Ardalan, \& Bakhtiar, 2015: 55)
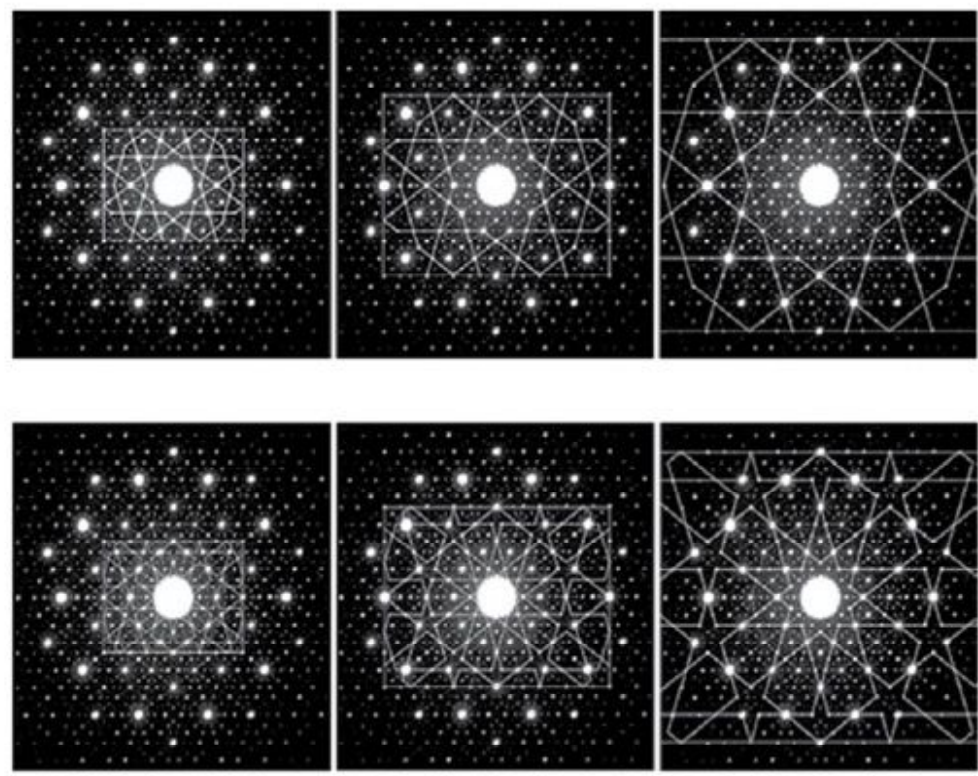

Picture 4. The geometric similarity of 'Girih' with the silicon crystal structure (Mohamadianmansoor, \& Faramarzi, 2012) 
The qualitative nature of all geometric shapes is a tendency towards a central purpose. It is as a result of harmonious lines that special shapes are created and multiple patterns are obtained. Because surfaces produce infinite patterns, they combine space and time into infinite repetitive patterns. (Ardalan, \& Bakhtiar, 2015: 73) For the Muslim artist, the most important issue is how unity appears in plurality and plurality refers to unity, which means Monotheism. This principle, which is related to an existential system, is not only for the artist but also for the Mystic and the Sufi. The purpose of the Muslim mystic or Sufi is also to justify how the world came into being and the world was developed, which is a diagram of plurality, from true unity, from the position of the One, which is pure Unity. How Creator has emerged from the rank of the essence of One, in the ranks of names and attributes in the universe. Achieving unity from plurality and expressing unity in multiplicity is a fundamental issue in wisdom and mysticism, that is, the purpose of the mystic in the wisdom is to reach true unity from plurality. This is also seen in art. We can say that art is a path of wisdom and a kind of mysticism, it differs in the way of expression and the materials it uses. (Awani, 1996: 341)

"As His Beauty had hundreds of thousands of shapes

There were different visuals for each particle

He finally spread (outspread) every particle

To show other faces of His Infinite Beauty

$\mathrm{He}$ is 'One', the root of the other numbers

To be Him breath of every other beloved"

- Shah Nimatullah Wali, (ganjoor.net). [Translation: Author]

There is no secret deeper than Light for Divine Unity (Burckhardt, 2007: 48) Light is inherently indivisible; The nature of light does not change due to the decomposition of light into colors and is not reduced by the gradual transfer of light in the darkness. In the same way, Nothingness does not exist by itself except through its imaginary contrast to existence. (Awani, 1996: 169) It should not be assumed that the word 'Light' refers only to sensory matters and something that has special photons and its quantity and quality is discussed in physics, but this is only one of the clearest examples of this word. Light refers to both physical light and metaphysical Light, and it is possible that sensory light radiance from unseen Light. (Al-Ghazali, 1985: 41) 
Naeim Sepehri: Wisdom and Mystical Thoughts on The Mirror-Tiles Art in Safavid Architectural Space and its Relationship With Sufism (page 291-314)

This Light, is the absolute light of God, and also in Islam, light has been introduced as a symbol of guiding humanity from darkness, so the reflection of light from mirrors with many fractures and various designs, in addition to creating a beautiful space, can also remind divinity of unity and Oneness. Light in Islamic architecture of Iran is not always used as a complete illumination of the architectural space, but sometimes it takes on the aspect of mysticism and sanctity and other aspects of the space such as color and texture are emphasized, the use of Mirror-tile art becomes more prominent. It indicates the attainment of multiplicity to divine unity. Among the symbols of unity, the deepest and most obvious symbol is light, which the Muslim artist knows well how to absorb, transmit, and radiate in a thousand different ways. Light is a single thing and it multiplies only through the intervention of darkness, which has no truth of its own. (Burckhardt, 2007: 114) Believing means creating Mirror-tiles of the ego, mirror-holding, and adorning the space of the soul with inner purity like pieces of a mirror, finding the talent and ability to looking at the face of God, and attaining the grace of meeting and observing the 'Friend'. (MullaSalehi, 1998)

"Everything you see is the Light of God

Don't think that He is separated from us

Open your heart's eye to be able to see

'Friend' face that is the light of our eyes"

- Hatef Esfahani, (ganjoor.net). [Translation: Author]

\section{Results}

Correlations are significant between Sufism and Mirror-tiles in terms of time. Also, its use in the Safavid period, which was based on Sufism, and behind the cover of mystical thoughts. The relative lineage of the Safavids dynasty before Sheikh Safi al-Din is ambiguous and contradictory, but with the birth of Sheikh Safi al-Din Ardabili, this family (Sufism) enters an obvious and clear stage of history. Using the topics and temporal relations between the mentioned persons and the Items cited in the body of the research, the process [Diagram 1] of the Mirror, Sufism, and Mysticism was drawn as follows: 


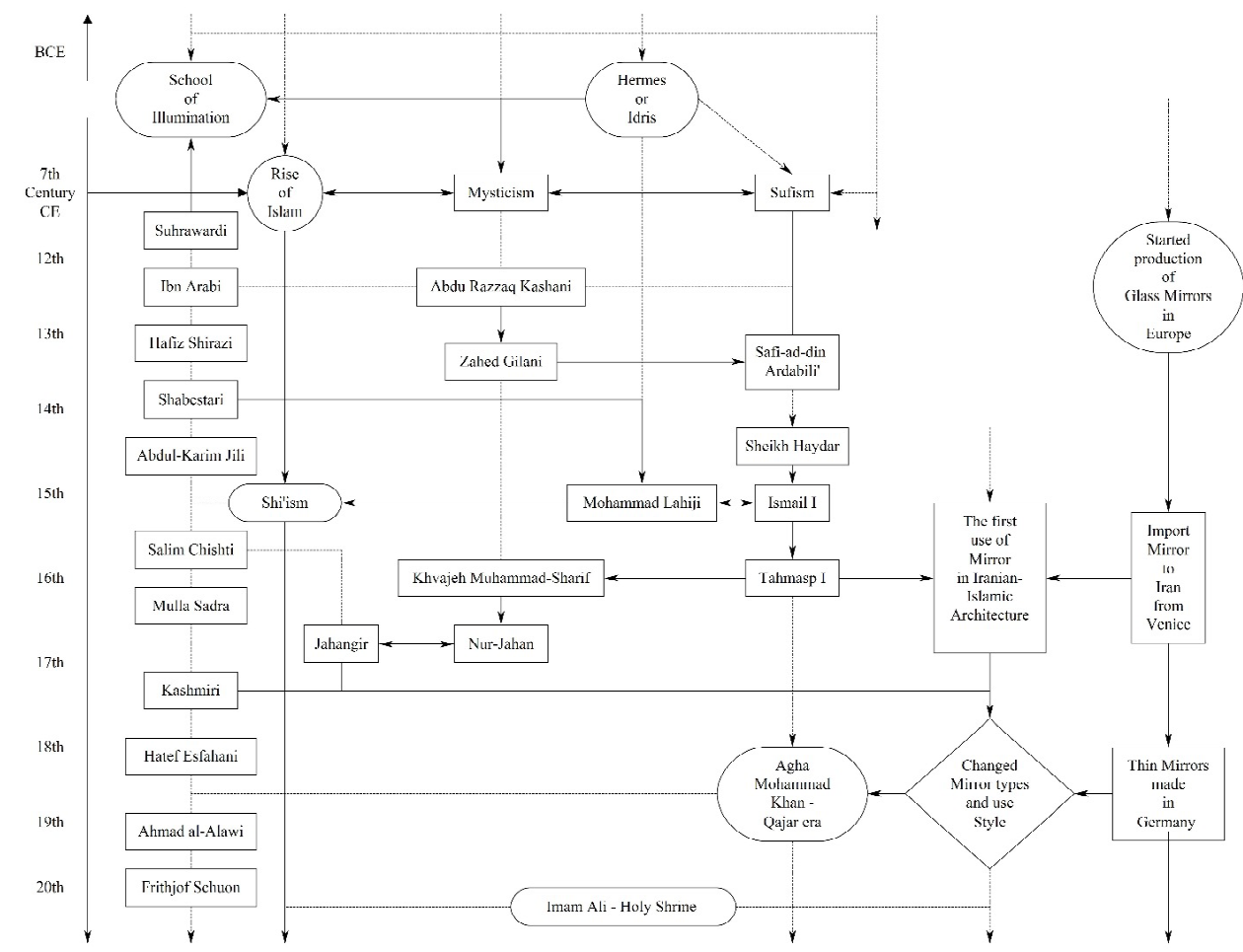

Diagram 1. The trend line of Mirror, Sufism, \& Mysticism, due to the times and persons mentioned in research (Design: Author)

The culture that governs Iranian traditional art and architecture, is the culture of 'Master \& Apprentice' education [like Sufi \& Disciple] and there are certain secrets that govern such a system. Mirror-tiled architectural spaces in the expansion and extension of unity and continuity movement and infinite suggestions in spaces that are dominated by stillness and limitation in volume and matter can have a greater impact and influence on human feelings and thoughts and make to think about the background of the wisdom in the aim of its creation. Understanding the mirror is very complex and difficult from the mystical point of view, and throughout history, scientists and philosophers have always tried to understand it. Two of the most important points of the Mirror-tiles are the manifestation of Divine Glory \& Beauty [Soul \& Light], and Multiplicity in Unity [Unity of Existence]. Which have been clearly [and using allegories] explained in Persian mystical literature. 
Naeim Sepehri: Wisdom and Mystical Thoughts on The Mirror-Tiles Art in Safavid Architectural Space and its Relationship With Sufism (page 291-314)

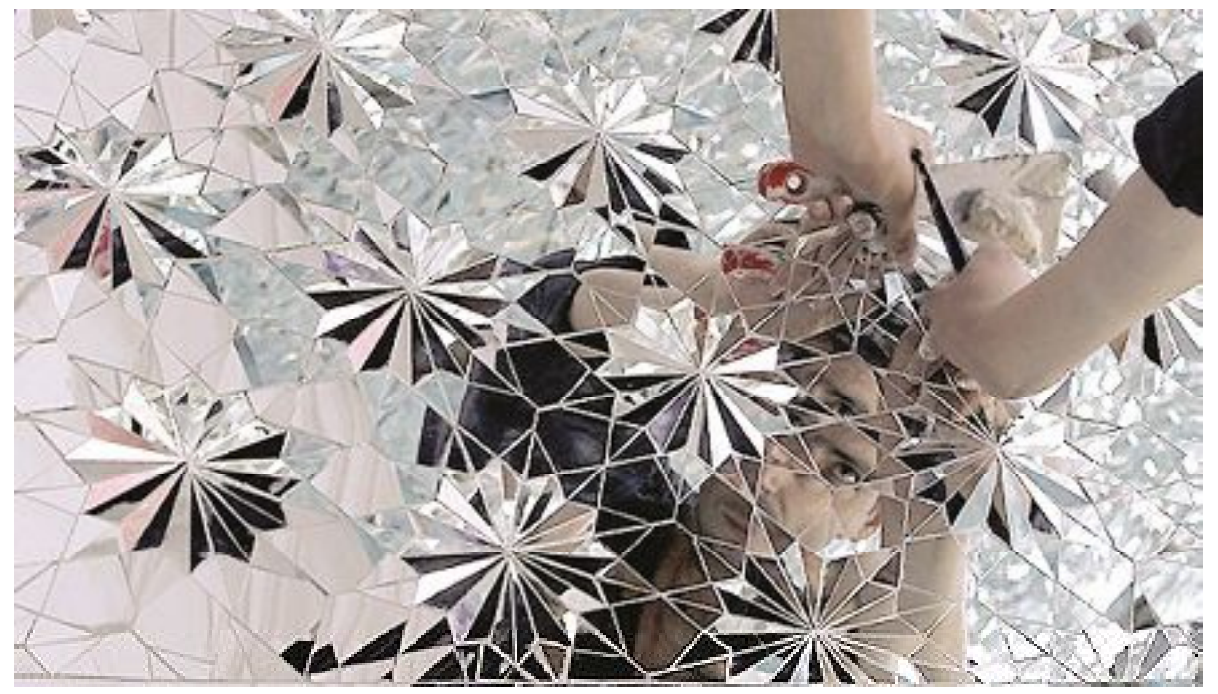

Picture 5. Mirror-tile working, Shah Abdul-Azim shrine, Ray, Iran (fhnews.ir, 2012)

A complete picture, when transformed into the different shapes and dimensions of the joined to each other little mirrors image in the architectural space, divide to the plurality reflection in broken images and to a particle in the mass of other particles in the unity, such as a fish that joins the sea or a drop that merges with the boundless ocean of existence. The mirror's geometry differs in the inside, state, and shape. So when the light has reflected from the mirrors, depending on the shape of the particular mirror, the radiated light takes the shape of its host. This is exactly the allegory of the manifestation of the One Divine Spirit in various forms and manifestations that have been expressed in different ways in Persian mystical literature by the Mystics.

One of the most import ant factors that engender the Safavid Empire was the establishment of a connection with Sufism and Mysticism and the use of this principle of existential unity mystical thought for the integration between different ethnic groups and individuals. Thus (after about 850 years) becoming the first native dynasty since the Sasanian Empire to establish a national state of Persia [officially known as Iran].

\section{Conclusion}

After reviewing some of the previous related research, the obtained data from relations have been rated through which the framework as follows respectively: First, from a brief history of mirror and Mirror-tile art parallel with Safavid Empire in relationship to Sufism and Mysticism; Second, 
analysis of spiritual and traditional art and wisdom of mirror, especially plurality in unity (unity of essence) about the aim of this research; And finally a comparative study of mystical poems related to each of the appointed subjects in the body of this research. The key to the mystical treasure is under the poet's tongue. Persian poetry, as literary art, has always contained a message that remains over time and [if possible] is difficult to distort because of its inherent nature, has always carried hidden messages from past Grand Masters illuminations, discoveries, and intuitions. The art of Mirror-tiles and the illuminant relationship of the mirror with the origin of creation [Light \& Soul $(\mathrm{Hu})]$ and how it is used as a symbol of a material element in immaterial expression, is symbolic and cryptic. Using Islamic illumination teachings and combining mysticism and Sufism thoughts in allegories of Light, Water, Mirror, and Number, and the Geometry as the sacred spiritual and traditional art in the direction of the transcendence of the ego to the Soul and the glorification of the appearance and presence of Truth in the earthly world, at the same time, Iranian Masters have emerged and transferred their perceptions of the sublime world to the earth. The basis of the art of Mirror-tile in mystical Islamic thought is based on the manifestation of the purity and divine glory of light in the mirror and plurality in unity, which symbolically and impalpable emphasizes discovery and intuition; As creation is the mystery and what carries the mystery is not known but it exists and its understanding is achieved through presence and experience. So, art in which there is no allegorical mystery and expression does not signify anything beyond itself, it is what it is and its appearance and interior are the same and it is not a mirror for the appearance of transcendental truths. [The ordinary language reflects the partial knowledge acquired through logic and emotion, but the language of symbolism expresses knowledge acquired through reason, that is Mysticism. (Ardalan, \& Bakhtiar, 2015: 35)] Mirror and existence is a symbol of Persian mysticism that is illustrated by the art of Mirror-tile. Plurality in unity and unity in diversity [unity of essence] in the different shapes and sizes of little mirrors being together as One single piece in an architectural space.

This study tried to clarify the wisdom in the Mirror-tile art from its beginning in the Safavid dynasty whit the Sufism past; Finally, the investigated relations between the import of the glass-mirrors from Europe to Persia (Todays-Iran) which has been used in the art of Mirror-tile in architectural spaces, regarding the aim of the present study as the background in 
Naeim Sepehri: Wisdom and Mystical Thoughts on The Mirror-Tiles Art in Safavid Architectural Space and its Relationship With Sufism (page 291-314)

Mysticism through the influence of the Persian mystical literature and thoughts about the Mirrors.

\section{REFERENCES}

Al-Ghazali, H., (1985). Meshkat-Al-Anvaar. Translator: Ayinevand, S., First edition, Tehran, Amir Kabir Publishing Institute. NBN: 1886708

Aliabadi, M., \& Jamalian, S., (2012). Recognition of Mirror Work Patterns in Qajar Monuments at Shiraz. Negareh Journal, Volume 7, Issue 23, Serial Number 23, (Summer 2012), 17-30.

http://negareh.shahed.ac.ir/article_52.html?lang=en [Last Access: 21/03/23] Ardalan, N. \& Bakhtiar L., (2015). The Sense of Unity: The Sufi Tradition in Persian Architecture. Translator: Jalili, V., Fifth Edition, Tehran, Architecture Science Institute. NBN: 2502424; ISBN: 978-600-534465-3

Awani, G.R., (1996). Spiritual Wisdom and Art: (Collection of Articles). First Edition, Tehran, Grrous Publishing. NBN: 1597277

Azaimabadi, H.G., (2012). Tadhkira-yi nishtar-i jishq: (Volume 1). Editor: H.S. Javadi, S.K., First Edition, Tehran, Publisher: Written Heritage. ISBN: 978-600-203-045-0; (Volume 1) ISBN: 978-600-203-046-7

Banks F., E., (1993). Nur Jahan: Empress of Mughal India. First Edition, Oxford, United Kingdom, England, University of Oxford University Press. ISBN 9780195074888

Bolkhari, H., (2018). Illusion and Beauty Geometry: A study on the views of The Brethren of Sincerity on the wisdom of art and beauty. Second Edition, Tehran, Publisher: Academy of Art. ISBN: 978-964-232-0417

Burckhardt, T., (2007), Fundamentals of Islamic Art. Translator: Nasri A., First Edition, Tehran, Haghighat Publication. NBN: 1105025; ISBN: 964-7040-93-8

Fallah G. Q., Aziznejad, R., \& Vaezi, A. (2016). The importance of Mirrortiles artwork in the Safavid and Qajar periods. International Conference on Civil Engineering, Architecture and Urban Infrastructure, Tabriz. https://civilica.com/doc/448394 [Last Access: 21/03/23] 
IBDA': Jurnal Kajian Islam dan Budaya

Gardner, H., (2015), Gardner's Art Through the Ages: A concise global. Translator: Islamiah, M, \& Darabi, H., et al. First Edition, Tehran, AGAH Publisher. NBN: 3855644

Grantovski, D., et al., (2006). Iranian history from the ancient to the present.

Translator: Keshavarzi, K., Fourth Edition, Tehran, Publisher:

Morvarid. ISBN: 978-964-8838-37-4

Hejazi, M., (2009). Sacred Geometry in Nature and Persian Architecture. Journal for the History of Science, Volume 6, Issue 2, Serial Number

2, (Summer and Autumn 2009), 15-36. ISSN: 1735-0573

https://jihs.ut.ac.ir/article_22386.html?lang=en [Last Access: 21/03/23]

Hekmat, N.A., (2006). Metaphysics of Imagination in Golshan-e-Raz

Shabestari. Second Edition, Tehran, Publisher: Academy of Art. ISBN:

978-964-8802-63-4

Izutsu, T., (2000). Sufism and Taoism: a comparative study of key philosophical concepts. Translator: Gohari, M.J., Firs Edition, Tehran, Rozaneh Publishing. NBN: 7816820; ISBN: 964-334-027-9,

Jamei, B., \& Saeedi, M.R., (2000), A look at the historical monuments and buildings of Ardabil, Editor: Qanizade, B., Second Edition, Ardabil, Buick Jamei - Scientific \& Cultural Publications. NBN: 72471

Jilani, A.K., (2013). The perfect man in late and early wisdom. Translator: Hoseini, S.A., First Edition, Qom, Publisher: Ayat Eshragh. NBN: 3219979; ISBN: 978-600-5321-92-0

Karimian.S, A., (2013). The Fundamental Principles of Aesthetics in Islamic Mysticism. First Edition, Tehran, Organization for the Study and Compilation of University Humanities Books (SMT). ISSN: 978-964530-872-6

Khavandmir, A.M., (1991). History of Shah Ismail and Shah Tahmasb Safavid (zeil -e Habib al-siyar, ). Translator \& Editor: Jarahi, M.A, Tehran, Gostareh Publication. NBN: 703947

Kiani, M.Y., (1997), Decorations related with the Iranian architecture of the Islamic period. First Edition, Tehran, Publisher: National Cultural Heritage Organization, Research Institute. NBN: 766728

https://www.mcth.ir [Last Access: 21/03/23]

Madkour, E., (2008), Symbolism in Ibn Arabi's Thoughts, Translator: Vafaei, D., First Edition, Tehran, Center Publication. ISBN: 978-964-2130-26-9 
Naeim Sepehri: Wisdom and Mystical Thoughts on The Mirror-Tiles Art in Safavid Architectural Space and its Relationship With Sufism (page 291-314)

Mohajeryzadeh, G., (2015). Hermes Structure in the Mysticism of Iran. Mysticism Studies, University of Kashan, Volume 1, Issue 21 And 0 (Spring \& Summer 2015), 181-214.

http://s-erfani.kashanu.ac.ir/article-1-750-en.html [Last Access: 21/03/23]

Mohamadianmansoor, S., \& faramarzi, S. (2012). A Comparison Between

Quasiperiodic Order of Shah Gereh and the Quasicrystal Structure of

Silicon. University of Tehran, Honar-Ha-Ye-Ziba: Honar-Ha-Ye-

Tajassomi, Volume 4, Issue 50, (Autumn 2012), 69-80. DOI: 10.22059/

jfava.2012.28940

https://jfava.ut.ac.ir/article_28940.html?lang=en [Picture 4], [Last Access:

21/03/23]

Motavali H., Y., (2008). Research on the position of Shi'ism and Sufism in

the political structure of the Safavid state, Journal of History, Third Year, Serial Number 11, (Summer 2008), 188-170.

https://www.magiran.com/paper/1065750 [Last Access: 21/03/23]

MullaSalehi, H. (1998). Iranian cinema: Glory Images in Islamic Architecture

of Iran. Farabi Magazine, Serial Number 29, (Summer 1998), 4-31.

https://www.noormags.ir/view/en/articlepage/311472 [Last Access: 21/03/23] Najafi, M., (2009). Postmodern Revolution and Islamic Civilization: Fourth Wave of Islamic Awakening. Second Edition, Tehran, Publisher: Institute for Iranian Contemporary Historical Studies. NBN: 1244928

http://www.iichs.ir [Last Access: 21/03/23]

Payind, A. \& McClimans, M., (n.d.). Key to Understanding the Middle East.

Chapter Two: Faith and Religious Identity, The Ohio State University Pressbooks, (PB), Open Course Materials from Ohio State Instructors. https://ohiostate.pressbooks.pub/key2mideast/chapter/shiism [Last Access: 21/03/23]

Pelsaert, F. (1972). Jahangir's India, the Remonstrantie of Francisco Pelsaert. Editors \& Translators: Geyl P. \& Moreland W.H., India: Idarah-i Adabiyt-i Delli.

[Dr. B. R. Ambedkar Open University Library. Cambridge W Heffer and Sons Ltd, (1925). 2005/05/19 Digital Version: https://archive.org/ details/jahangirsindia035084mbp/page/n49/mode/2up], [Last Access: $21 / 03 / 23]$ 
Poorzarrin, R. (2014). A Comparative Study of the Visual Signs of Persian Mirror work and the OP [Optical] Art Painting. Negareh Journal, Volume 8, Issue 27, Serial Number 27, (Spring 2014), 75-86. http://negareh.shahed.ac.ir/article_117.html [Last Access: 21/03/23] Riazi, M., (1996). Illustrated Dictionary of Iranian Art Terms, First Edition, Tehran, Publisher: Al-Zahra University Research Association. NBN: 772431

Roshna Kapadia, (2018). Bichitr, Jahangir Preferring a Sufi Shaikh to Kings. in 'Smart history', (September 14, 2018), Accessed September 6, 2020. https://smarthistory.org/bichitr-jahangir-preferring-a-sufi-shaikh-to-kings [Last Access: 21/03/23]

Taghavi, N., (2015). Study of the wisdom of the Mirror-tile in Islamicarchitecture. International Conference on Human, Architecture, Civil Engineering and the City, Tabriz.

https://civilica.com/doc/409916 [Last Access: 21/03/23]

Torkaman, A., \& Farshchian, AH. (2016). The productivity of mirror art in stylizing the architectural space according to the re-creation of Islamic architectural space. Volume 2, Number 10 \& Volume 1 of Arts and Humanities Studies, (December 2016). 43-49.

http://ensani.ir/fa/article/369901 [Last Access: 21/03/23] http://fhnews.ir/fa/news/64402 [Picture 5], [Last Access: 21/03/23] https://ganjoor.net [Persian poems], [Last Access: 21/03/23] https://imamali.net/?id=6188 [Picture 1 - Photo reports], [Last Access: 21/ 03/23]

https://khanacademy.org/humanities/ap-art-history/south-east-se-asia/indiaart/a/bichtir-jahangir-preferring-a-sufi-shaikh-to-kings [Picture 3 Roshna Kapadia], [Last Access: 21/03/23] https://quran.com [Quranic verses], [Last Access: 21/03/23] 